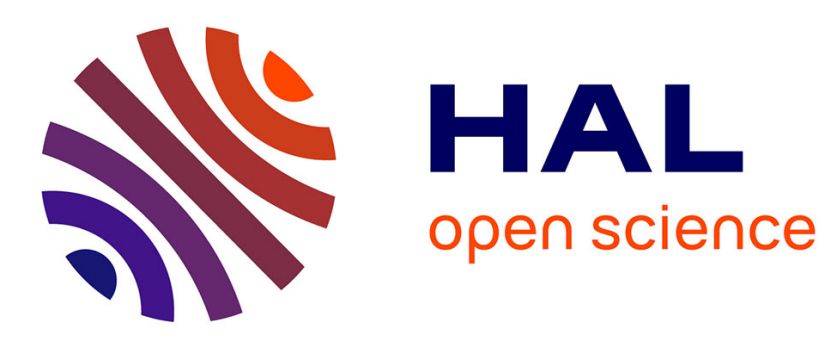

\title{
The Lunchbox and Mumbai's Dabbawallahs: Creating Spaces of Desire
}

\author{
Joshil K. Abraham, Judith Misrahi-Barak
}

\section{To cite this version:}

Joshil K. Abraham, Judith Misrahi-Barak. The Lunchbox and Mumbai's Dabbawallahs: Creating Spaces of Desire. Etudes Anglaises, 2018, 71 (3), pp.341-354. 10.3917/etan.713.0341 . hal-03259004

\section{HAL Id: hal-03259004 \\ https://hal.science/hal-03259004}

Submitted on 16 Sep 2021

HAL is a multi-disciplinary open access archive for the deposit and dissemination of scientific research documents, whether they are published or not. The documents may come from teaching and research institutions in France or abroad, or from public or private research centers.
L'archive ouverte pluridisciplinaire HAL, est destinée au dépôt et à la diffusion de documents scientifiques de niveau recherche, publiés ou non, émanant des établissements d'enseignement et de recherche français ou étrangers, des laboratoires publics ou privés.

\section{(ㅇ)(1) $\$$}

Distributed under a Creative Commons Attribution - NonCommercial - NoDerivatives| 4.0 

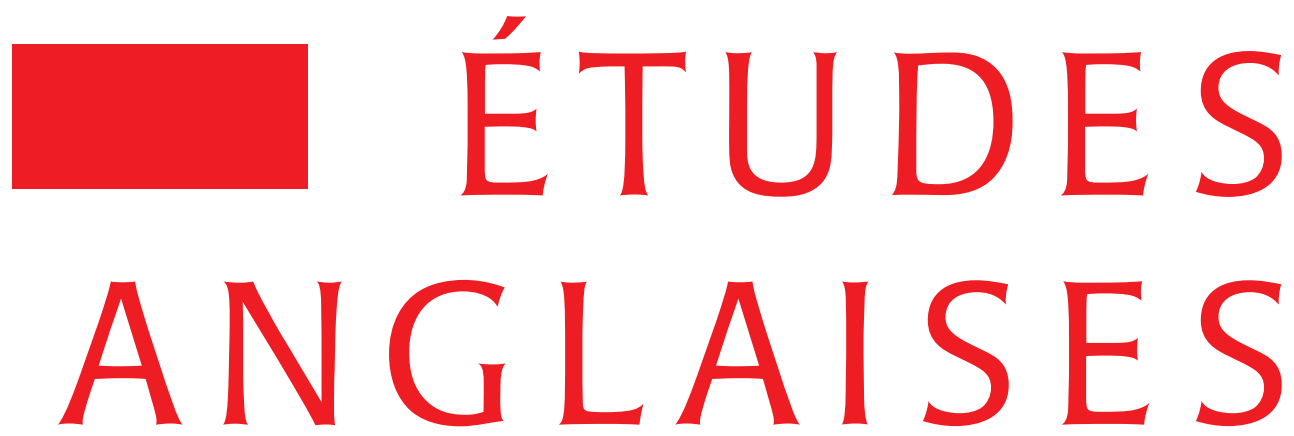

revue du monde anglophone

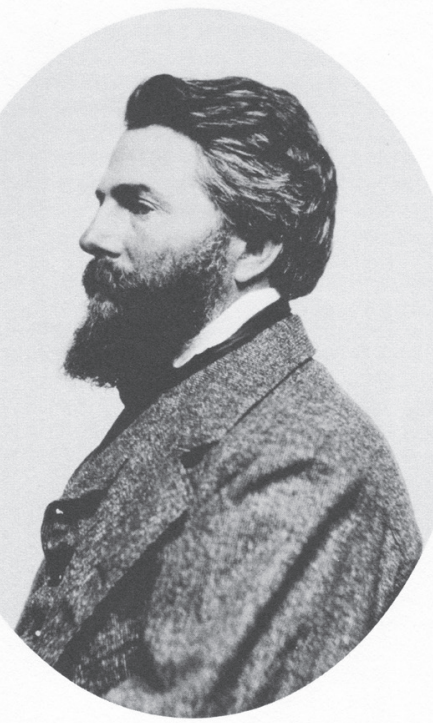

juillet-septembre

2018 $71 / 3$
Didier Érudition

Klincksieck 

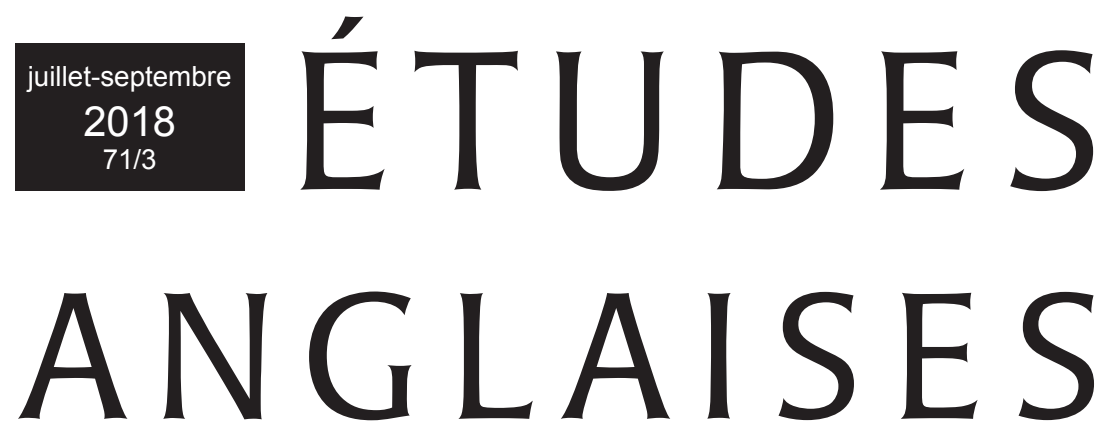

\section{Sommaire}

\section{ARTICLES}

Eugenio F. BIAGINI : Home Rule for Ireland (1874-1914): the Great Missed Opportunity?

Fiona McCANN : Borders, Barriers and Kinopolitics in Nadine Gordimer's Jump and Other Stories (1991)

Christine SUKIC : "Such a mistake as I have often seen / In a play": The Duchess of Malfi, a Tragedy of Errors

Michel IMBERT : The Confidence-Man : l'inconfiance de l'homme des foules

Atonement: A Conversation with Ian McEwan. Edited by Vanessa Guignery

\section{VARIA}

JoshilK.ABRAHAM and Judith MISRAHI-BARAK: The Lunchbox and Mumbai's Dabbawallahs: Creating Spaces of Desire...

\section{COMPTES RENDUS}

Sébastien SCARPA, Poétiques de l'affect. La poésie préromantique anglaise en contexte (L. Folliot), 355. - William HAZLITT, Sur l'amour de la vie et autres essais (L. Folliot), 357. - Philip DAVIS, The Transferred Life of George Eliot. The Biography of a Novelist (A. Jumeau), 360. - Anthony TROLLOPE, Les Tours de Barchester (H. Picton), 362. - Walter PATER, 
La Renaissance : Études d'art et de poésie (Cl. Masurel-Murray), 364. Redmer YSKA, A Strange Beautiful Excitement: Katherine Mansfield's Wellington 1888-1903 (A. Jumeau), 366. - Jodie MEDD (ed.), The Cambridge Companion to Lesbian Literature (F. Regard), 367. — Jason ALLEN-PAISANT, Théâtre dialectique postcolonial, Aimé Césaire et Derek Walcott (K.-J. Wallart), 368. - Vanessa GUIGNERY (ed.), The B.S. Johnson-Zulfikar Ghose Correspondence (G. Letissier), 371. VANESSA GUIGNERY, Jonathan Coe (C. Bernard), 373. - JOSHIL K. ABRAHAM and JUDITH MISRAHI-BARAK, eds. - Dalit Literatures in India (A. Tadié), 375.

Notes on Contributors ……........................................................ 378

Notes for Authors .............................................................................. $\quad 380$

Illustration de couverture :

Herman Melville en 1860.

(Berkshire Athenaeum, Pittsfield, Mass., WikiCommons) 


\section{VARIA}

Joshil K. ABRAHAM and Judith MISRAHI-BARAK

\section{The Lunchbox and Mumbai's Dabbawallahs: Creating Spaces of Desire ${ }^{1}$}

India is often hailed as being the biggest democracy in the world. Yet, it is a society where the contrasts between the achievements of the upper classes and the situation of the lower classes are among the sharpest. This article will use Ritesh Batra's The Lunchbox (2013): this fiction film offers an original vantage point into Indian contemporary society, not necessarily the one that is most often exhibited. It is the socio-economic world of small employees commuting by train between Mumbai and its remote outer districts, it is also the domestic world of wives and mothers. Most importantly, the network of relations in which the individuals are enmeshed, constitutes the core of the film. Through comedy and specific narrative devices such as letter-writing, or a non-linear time line, the film explores ways to prevent the foreclosure of one's lives in an increasingly consuming, devouring society. Ultimately, how can one emancipate oneself from material conditions, family bonds and social customs, and create new spaces for oneself?

L'Inde est souvent présentée comme la plus grande démocratie au monde. Pourtant, c'est une société où les contrastes entre la réussite des classes supérieures et la situation des classes inférieures sont les plus criants. Cet article s'appuie sur The Lunchbox (2013) de Ritesh Batra: ce film de fiction offre un point de vue original sur la société indienne, bien différent de celui qui est souvent adopté. Il s'agit ici du monde socio-économique des employés de bureau effectuant en train leurs trajets journaliers entre Mumbai et ses banlieues éloignées, ainsi que du monde domestique des épouses et des mères au foyer. C'est surtout le réseau de relations dans lesquelles les individus sont pris qui est au centre du film. Sur le mode de la comédie et en utilisant des procédés narratifs spécifiques comme le genre épistolaire ou une

1. Ashutosh Bhardwaj, Jayan K. Cherian, John McLeod and Nicole Thiara must be thanked for the useful insights they graciously provided at various stages of the writing of this article. The comments made by the journal's anonymous peer-reviewers are also gratefully acknowledged. 
structure temporelle non-linéaire, le film pose la question du verrouillage des vies individuelles dans une société de consommation de plus en plus dévorante. Comment s'émanciper des conditions matérielles, des liens familiaux et des coutumes sociales? Comment créer de nouveaux espaces de liberté ?

India is often hailed as being the biggest democracy in the world. Yet, it is a society where the contrasts between the achievements of the upper classes and the situation of the lower classes are among the sharpest. Specifically, the caste system still pervades the whole of society; socioeconomic relations are still moulded by tradition and inheritance; family and religion are central; exclusion and privilege are still rife. It is a known fact that the lower-class workers in India, who happen to be largely the lower castes, are considerably underpaid. Is it the cheap availability of labour or the caste system that fosters such a situation of low payment? The lower classes who in most cases are also lower castes, end up in cities like Mumbai and Delhi as unskilled labourers, employed on lower wages. They are forced to continue with their traditional jobs, such as manual scavenging, cleaning houses and streets, mending, washing and ironing clothes, etc., in the modern cities, earning the same wages they used to get. This stands in contrast with the modern European cities where it is often possible for the lower classes to break free from their traditional jobs and, if not, at least earn higher wages. It seems that the Indian cities work outside the purview of modernity when it comes to the lower classes and the lower castes. There is a complex intermingling of caste and class in India regarding the distribution of jobs and wages, all the more complex if one looks at the intersections with the different religions in India. ${ }^{2}$

As a fiction that was originally meant to be a documentary, the film The Lunchbox by Ritesh Batra (2013) offers a unique and original vantage point on contemporary Indian society, not necessarily the one that is most often exhibited. We will further examine how the film works against such a rigid economic and socio-political configuration by focusing on specific cinematic devices that belong both to the documentary genre and to fiction.

5,000 dabbawallahs in the city of Mumbai deliver some 130,000 dabbas (metallic lunch boxes), engaging in 260,000 transactions each day, six days a week, fifty-two weeks a year, minus holidays. As Stefan Thomke says in the article he published in the Harvard Business Review after conducting an extensive survey of the Mumbai dabbawallahs:

2. The lower castes that are not Hindu seem to be making better progress compared to their Hindu counterparts, which is evident from the report. See "Dalits in the Muslim and Christian Communities: A Status Report on Current Social Scientific Knowledge," prepared by Satish Despande and Geetika Bapna:

$<$ http://www.ncm.nic.in/pdf/report \%20Dalit $\% 20 \% 20$ reservation.pdf > last accessed 30/10/2018. 
The [dabbawallah] service is legendary for its reliability. Since it was founded, in 1890, it has endured famines, wars, monsoons, Hindu-Muslim riots, and a series of terrorist attacks. It has attracted worldwide attention and visits by Prince Charles, Richard Branson, and employees of Federal Express, a company renowned for its own mastery of logistics. (Thomke 1)

In the movie, Ila, in her endeavours to regain her husband's love, prepares a very tasty meal that is supposed to be brought to him by the dabbawallahs who deliver their lunchboxes to thousands of office workers in Mumbai. But a mistake is made and Ila's dabba is delivered to Saajan Fernandes, a widower on the eve of retirement, played by Irfan Khan. After the deviation of the dabba triggers this chance virtual meeting, an improbable exchange takes place between the two lonely souls: notes, then letters, gradually come with the food, whetting Ila's and Saajan's appetites and opening up opportunities to extricate themselves from the worlds in which they are locked up. Shaik, the trainee who has been put under Saajan's responsibility, played by Nawasuddin Siddiqui, also comes to share in the food, thus crossing some of the boundaries set up in the work place. Introducing more deviations from the prescribed social codes and mores is one of the objects of the film.

Ritesh Batra's angle is the socio-economic world of small employees commuting by train between Mumbai and its remote outer districts, it is also the domestic world of wives and mothers. This network of relations in which individuals are enmeshed, or try to emancipate themselves from, constitutes the core of a film that helps us understand better the inequalities that are at the heart of Indian society. Ultimately, how can one emancipate oneself from material conditions? How can one disentangle oneself from familial bonds and social customs?

The documentary was never shot as such by Ritesh Batra, it became instead a feature film that was jointly produced by Indian, American, German and French studios. ${ }^{3}$ It won the Caméra d'Or at the Cannes Film Festival (Semaine de la Critique), and met with quite an important success, first in India and then in France, though it differed from the big blockbusters from Bollywood and Kollywood one often associates with Indian cinema. ${ }^{4}$

3. The film was jointly produced by various studios including DAR motion pictures, UTV Motion Pictures, Dharma Productions, Sikhya Entertainment, NFDC (India), ROH Films (Germany), ASAP Films (France), and the Cine Mosaic (United States).

4. It is not as if the discussion of class, caste and social spaces is totally absent from Indian cinema. The (dis-)engagement with social spaces has been a feature of many Indian films, whether Bollywood or independent, since the 1930s. There are films that tackle socio-political issues in Indian society in a frontal manner using the angle of the socio-political drama: Jeevan Prabhat by Franz Osten (Hindi, 1937), Sadgati by Satyajit Ray (Hindi, 1981), Saptapadi by Kashinathuni Viswanath (Telugu, 1981), Bandit Queen by Shekkar Kapur (Hindi 1994, a biopic of Phoolan Devi), Samar by Shyam Benegal (Hindi, 1999), Kovilpatti Veeralakshmi by K. Rajeshwar (Tamil, 2003), Chithariyavar by Lalji George (Malayalam, 2004), Soul of Sand by Sidarth Srinivasan (Hindi, 2010), Khap by Ajay Sinha (Hindi, 2011), or Papilio Budha by 
The Lunchbox opens on a few shots of the trains on the Mumbai Suburban Railway system, on the crowds of commuters, on the shoe shiners who work in the stations, on the dabbawallahs. These shots are quite rapid but are enough to give us the context and make us understand the system set up by the dabbawallahs. They collect the dabbas from their customers' houses, they put them on their bicycles, carry them onto the train and take them out of the train to bring them to the clerks and office workers the dabbas are to be delivered to. We are taken into a very specific socio-economic stratum of Indian society, the world of office clerks, small company employees, commuters, etc., as far from "Shining India" as from the slums of Slumdog Millionaire. ${ }^{5}$ The very geography of Mumbai, whose urban expansion is only possible into sprawling outer districts, further and further away from the peninsula itself, creates the need for more suburban trains. This in turn prompts the need for delivery people to deliver the dabbas to the employees who rely on them for their lunch. From a sociological point of view, several elements can explain such a situation. It is too costly to eat lunch outside, the few office cafeterias are very low quality, better-quality fresh meals can also be prepared at local canteens, and for a monthly wage these meals can be collected and delivered by the dabbawallahs. The trains are too crowded and it would not be easy to carry the dabbas on the train to work; the heat being so high during so many months of the year, it would not be safe to keep the food out of the fridge from the early morning hours until lunch time.

Moreover, if people tend to prefer home-cooked food, it is also on grounds of food restrictions that are connected to caste and religion. Food is a deeply caste-ridden category in as much as people from different castes do not share food with each other. This starts from the divide between vegetarian and non-vegetarian practices, reflecting upper-caste and lower-caste food preferences respectively. Further, the fact remains that beef is generally consumed only by the Dalits, Adivasis, Christians and Muslims and this list of food-induced divisions based on religion and caste can be endless. It is often a matter of controversy and conflict in India.

Collecting the home-cooked meal in the morning and bringing the empty dabbas back after lunch, at off-peak hours, presupposes that the women do not work, that they are housewives who do not do anything

Jayan K. Cherian (Malayalam, 2013). On the other hand quite a few romances between men and women who belong to different classes/castes denounce caste-based discrimination obliquely: Achhut Kannya by Franz Osten (Hindi, 1936), Sujata by Bimal Roy (Hindi, 1959), Ankur by Shyam Benegal (Hindi, 1974), Masaan by Neeraj Ghaywan (Hindi, 2014), Fandry as well as Sairat by Navraj Manjule (Marathi, 2013 and 2016 respectively).

5. "Shining India" was a political and marketing slogan coined and promoted by the Bharatiya Janata Party (BJP) at the time of the 2004 general elections. It was also meant to promote India abroad. 
but cook for their husband and look after their children. The film very clearly points at the ambivalent status of women in Indian society. Three women characters embody a certain type of middle-class family environment where the woman appears to be defined only through her relationship to her husband and children. Once the context has been delineated in a few shots, the camera takes us first towards Ila, the main female character in the film, played by Nimrat Kaur. She belongs to the Indian middle-class, lives with her husband and daughter in an apartment in the suburbs of Mumbai. Her husband, like hundreds of thousands of other employees, commutes to and from work, morning and evening, using the Mumbai Suburban Railway system and waiting for his dabba to be delivered to him. He is very much in the background and barely appears as a full-fledged character in the film: the camera hardly ever lingers on him. He has in fact an affair with another woman and he merely passes through. We, the audience of the film, do not see him in detail, there are few close-ups or medium shots on him. In the double shots where he is present, the focus is on Ila, not on him. Whenever he is in the frame, the predominant shot that is used is the point of view shot, signalling to the audience that they will perceive the implications of what he sees better than he does, having a better grasp of what is in his field of vision than he does.

The second woman that features in an important way is Auntie Deshpande. She is paradoxically never seen in the film, but only heard from above through the open windows: Auntie is Ila's upstairs neighbour and they communicate through the window, passing baskets of food and spices back and forth, up and down. They also exchange stories and intimate memories and thoughts. Auntie never leaves her apartment because her husband is bed-ridden and dying. The third woman who is given some prominence is Ila's mother, and she too is only defined through her relationship to her husband, also bed-ridden and also dying, reduced to a shadow in the other room, then to a body to be wrapped up in a shroud for cremation.

In all three cases, food is a central trope of connection and desire, or the absence thereof. Ila prepares the meals for her husband in the hope it will ignite the old flame again and take both of them back to when they had their daughter. In one of the few scenes where husband and wife are seen together, Ila tries to make her husband notice how she has not changed that much since the early days of their marriage- she can still get into the outfit she was wearing on the first day of her honeymoon, she can still be desired as a woman and not be reduced to her role as a mother and wife. The husband, Rajiv, does not even notice that she is hinting at the possibility of their having another child, which is the only way she can suggest making love again. In the same way that he does not notice he has been getting the wrong dabbas, he seems totally oblivious to her desire and pretends not to notice her advances. Confronted with his unresponsiveness, Ila is left to her own devices. She can only find 
substitutes for her unanswered desire, which gets deferred through the fact that the dabba is exchanged and reaches another person than her husband. When the wrongly-delivered dabba comes back home empty, she feels her attempts to rejuvenate her husband's desire have worked, only to realise in the evening that it was not delivered to her husband since he mentions a dish she had not prepared. Taking her cue from the deferred attempt, she makes use of the deferral by continuing to send the sophisticated, delicious food to the other person, signifying her own desire and persisting in her attempts to find an object for it. In a Derridean sense, what is not there, what is both deferred and delayed, becomes more important than what is there. ${ }^{6}$ Homi Bhabha's perspective on, and quoting of, Fanon is also useful here to define desire:

As soon as I desire, I'm asking to be considered. I am not only here-and-now, sealed into thingness. I am for somewhere else and for something else. I demand that notice be taken of my negating activity insofar as I pursue something other than life; insofar as I do battle for the creation of a human world - that is a world of reciprocal recognition. (Bhabha 8)

The film indeed traces Ila's demands to be considered. She succeeds in her attempts insofar as the dabba exchanges continue, until the moment when the suggestion is made to meet in person. Unlike earlier moments when the man (husband) asserted his masculinity and his dominance in the family gender roles, Saajan is unable to get on with the meeting. He remains at the periphery, looking at Ila from a distance while she is anxiously waiting for him in a café. The realisation that there is such an age difference prevents him from the possibility of assuming a role that would be outside the usual social boundaries and gender role definitions. It is the only scene when they actually come close to meeting but even gazing is unbalanced-she is unaware she is being watched by him. It seems desire cannot be taken further.

In the case of Ila's mother and Auntie Deshpande, desire has also already stalled, and food appears as a substitute for the long-lost desire. When Ila's father dies and Ila comes to be with her mother while the body is taken away, mother and daughter have this quite striking, intimate conversation: Ila's mother talks about her feeling of relief and liberation following her husband's death, associated with a sudden craving for food (parathas particularly). For Ila the deferral of desire then becomes entrenched but, paradoxically, it triggers her liberation from the family

6. "This is why the $a$ of différance also recalls that spacing is temporization, the detour and postponement by means of which intuition, perception, consummation-in a word, the relationship to the present, the reference to a present reality, to a being-are always deferred. Deferred by virtue of the very principle of difference which holds that an element functions and signifies, takes on or conveys meaning, only by referring to another past or future element in an economy of traces. This economic aspect of différance, which brings into play a certain not conscious calculation in a field of forces, is inseparable from the more narrowly semiotic aspect of différance." (Derrida 218) 
who stifle her in a domestic frame laden with Indian traditional customs perpetuated into modernity. Only then does she decide to move out of the boundaries of the nation and far from family obligations and restrictions: Bhutan, both close and other, outside the nation but contiguous to its boundaries, appears as a possibility to relocate and reinvent herself.

From another angle the dabba prepared by Ila and the dabba prepared by the canteen for Fernandes are valued differently in terms of wealth. The work performed by Ila is not granted any value, monetary or otherwise, neither by her husband nor in extension by Fernandes. On the first day, when Fernandes gets the food cooked by Ila without knowing it had not been cooked by the canteen, he goes to the reception of the canteen and compliments them on how good the food was. Even though Saajan has taken pleasure in the food that has revived his taste buds and stimulated him anew, he cannot acknowledge Ila directly. Even though she had made the effort to write to him in the first place, along with sending a delicious meal, he is unable to direct his compliments to the woman who has prepared this special meal, he is only able to send back a message to her complaining that "the food was very salty today." Even if he had known the previous day that it was Ila who had prepared the food, he would probably still have been unable to direct his compliments to her. The domestic work done by women comes for granted, it is not considered as work and no particular value is attributed to Ila's cooking. On the other hand, the cooking done by Shaik is appreciated by both his wife and Fernandes, it is viewed as an important contribution to the household. Gender spaces are entrenched within economic spaces. The gender roles that determine cooking and its worth in monetary and emotional terms is also part of the issues raised by the film.

The early shots make us understand quite rapidly that the film is all about social space(s), and how these spaces are drawn up, and locked up, in Indian society: the domestic space, the space of the office, and the public, mostly urban, space, but also the socio-political space that is open, or closed, to such or such category of people. They stand quite separate, and so do the individuals who inhabit them. The film makes visible the different ways of transforming space into a place of one's own, or not. This is precisely the predicament the characters of the film find themselves in. For quite a while, at the beginning of the film, Ila is seen only at home, in the kitchen or in her daughter's bedroom. The social space of the business world, or rather small companies' world, is embodied by Saajan Fernandes: as a widower on the eve of retirement, he does not expect much from life any more. The office that is shown on screen is in his image, it is still resisting technological evolution and has not stepped into the electronic and digital $21^{\text {st }}$ century. When Saajan's boss puts under his responsibility the new recruit who will take over from him when he retires, this comes as a burden, or rather as an intrusion. Shaik expects to be trained, he smiles a lot, he is eager, he invades Saajan's space, he intrudes into his well-ordered schedule, forces him 
into conversations, follows him on the train in the evening. He goes as far as sharing his food with him.

If one looks more precisely into the spaces the three characters evolve in, one finds reflections of Indian society. The names reveal religious and social origins. While Ila's family is Hindu and Shaik's is Moslem, Saajan is not seen as practising any particular religion but through his name, Fernandes, it is the Portuguese and Christian world that are alluded to. So the three main religions practised in India are represented through the three main characters in the film, thus pointing to the disconnection between social groups and religious communities. Ila is hardly seen interacting with anyone but her neighbour upstairs-we only hear her voice and see what she puts in the basket that moves up and down between the two floors. For Saajan, having to interact with anyone is unpleasant at best and painful at worst (his neighbours, people on the train, the kids on his street, his trainee...). As for Shaik, however hard he tries to interact with people, the hurdles he faces are innumerable: as he is probably coming from a lower class or caste, the parents of the woman he loves do not want him as a son in law, the man who is supposed to train him is not interested in having him as a trainee, etc. He is always intruding in a space that is not considered as rightfully his and one guesses that he had to work his way up the social ladder the hard way, possibly even faking his degree and recommendations to get his job. For the non-privileged classes social space is restricted and the constraints incite people to find other, more devious ways. One example of this would be the fact that Shaik has to travel in the first-class compartment to be friends with Fernandes, thus emphasising the class-divided society in Mumbai. While the dabbawallabs who bring the food have to travel in the second-class compartment and their journey is accompanied by their "folk songs," Shaik has to upgrade his ticket to be in Fernandes' company.

Once he has become friendly with Saajan, Shaik asks him to stand in as his family at his wedding. Not only did he have to invent degrees and recommendations to get himself hired but he, the orphan, also has to invent a family for himself to be accepted by his in-laws. The underprivileged are so vulnerable that they have to become the tricksters of their lives to sustain themselves, bypassing obstacles and circumventing rules.

The film clearly foregrounds the desire for upward mobility in the Indian context: that of the Christians (Saajan Fernandes), and that of the Muslims (Shaik) in terms of class. Shaik's upward mobility and Fernandes's apparent resistance point to the complexity of these issues among non-Hindus. Ultimately Fernandes becomes a foster father figure for Shaik when his marriage happens, replacing his invisible family. It seems that only among the non-Hindus has he been able to find a support system he can make use of. There seems to be a larger possibility for the non-Hindus to move up the social ladder compared to their Hindu counterparts, even if this requires a certain number of tricks and adjustments to be performed. 
This well-oiled social machine comes to be disturbed when a mistake occurs in the delivery of the dabbas. Spaces collide and boundaries get blurred. The people who were not meant to be in contact suddenly are, albeit virtually, and they are creating hybrid, heterogeneous spaces, what Bhabha calls "third spaces," those "interstitial, disjunctive spaces" (Bhabha 217), through which new subjects emerge. As symbolized by the deviated dabba, people start exceeding their appointed spaces. If the beginning of the film was all about separate spaces, the film is actually working against such separate spaces and a generally-shared feeling that this is how it is, that one cannot do anything against this socio-economic rigid structure. The film works towards establishing connections, freedom and desire where there were not any.

Food can be a dividing factor in Indian society, or rather the expression of the divisions at work in Indian society. However, in the film, food is turned into the main connecting device from a thematic point of view and it is precisely what triggers the renewal of desire. Saajan starts to live his day at work for the pleasure of opening his dabba, sometimes even leaving his desk early and baffling his colleagues. Food also opens a new geography of contact since he invites Shaik to share his meal. The food has already connected him virtually to a woman he has never met, it now connects him to a man he had never thought he would ever get close to. Shaik starts telling him personal details about his life and invites him to his home for a meal. He has learnt to cook when he was working in Saudi Arabia, and he is the one who cooks at home, all the more so when it comes to inviting his trainer. In this instance, gender roles are being changed around when it comes to lower classes. Also, the food Saajan is served at Shaik's is not the vegetarian cooking of the upper-caste Hindu community, it is pasanda, a traditional mutton dish that is cooked in the Moslem community. The space of, and the space between, the religious communities is made palpable again, just as the social spaces mentioned earlier, but this time it is to connect, not divide. Food is one of the elements in the film that create a connection where there was none. It is the thematic element that recreates desire where it had vanished. The dabba is one of the first elements that is used in the scenario to reach that purpose, it is given a life of its own and is turned into a character which controls the narrative. For example: the dabba is sent full, or empty, with too much salt, or too much chilli, and it is what brings newness to Saajan's and Ila's lives. It prompts them to re-invent themselves. However, it is the rhetorical construction of the film and its editing that underline and reinforce this desire for connections, and this is done in several different ways.

The narrative of the film is (re-)organised through the literary device of notes and letters, exchanged through the dabbas once the delivery mistake has been identified. Ila is the one who takes the initiative with the second dabba and surprises Saajan by sending a short note in between 
two chapatis, explaining how she had cooked that food for her husband. After licking his fingers, Saajan sends back a short note in the empty dabba saying, in English, "The food was very salty today." The following day, the food is not "too salty" any more but it has much more chilli! Yet, dabba after dabba, letter after letter, an abstract space is created, an imaginary and emotional one, a relationship is built, more and more personal details are being exchanged and the lives of both characters are restructured through the notes they write to each other and that become letters. A "third space" is created, a common experience to share albeit virtually and at a distance. If the dabba has been following a deviating route, and appears to have been purloined, almost following a path of its own, the letters certainly reach their destinations, albeit in secret and hidden away from the public gaze. It is almost as if a pact had been signed between the two individuals but one that is impossible to valorise in public. Even if it must remain secret, being hidden away in pockets or on the body itself, the function of the letter is to remain a singular whole that cannot be taken away from its owner. ${ }^{7}$ It is interesting that such a space is shared mostly in English (especially on Saajan's side): the Hindi language is already inscribed in the social power structures, mostly because caste divisions surface in the Indian languages. English may contain class and gender divisions but not caste ones.

This space of connection is amplified through the editing and particularly through the handling of cinematic time. The first instance of time that veers off the chronological axis happens when Ila reads Saajan's second letter: he tells her how he ate the chilis and quelled their fire with a banana. As Ila reads the letter in the afternoon, Saajan's voice is heard delivering his words, projecting us back to the time he was writing the letter at lunch time. To these two moments that are combined together, a third one is added since the image that is projected onto the screen shows Saajan walking in the street after lunch, eating his banana and watching the other employees having a quick bite. Flashbacks are undoubtedly common in films. Yet, here, the flashback is used in a way that highlights once again an improbable connection between the characters. Diegetic time is handled in a non-chronological way and this is fused with a particular handling of space. In The Lunchbox, the critique of the regulation and codification of social space in India is made conspicuous through the disruption of space and time schemes on the screen, pointing to the urgent necessity to create interstices, gaps, incongruity, and ultimately, movement, connections, and freedom. In the instance that was referred to above, three different "timeimages" are shown through different "movement-images."

Additionally to the device of the diegetic voice-over that is constantly resorted to in the film, the editing draws attention to the connections that

7. This has been inspired by Lacan's seminar "La Lettre volée," a seminar delivered on April 26, 1955. 
the scenario has introduced between the characters. At one moment, Ila is writing a letter to Saajan, discussing Auntie Deshpande, her neighbour, and reporting Auntie's words about her husband's illness and how he feels connected to the electric fan revolving above his head. The day the fan stops, he will die. When Ila's voice is heard, speaking the words of her letter and reporting yet another woman's words, the fan above Saajan is shown on the screen and Saajan makes the connection and feels as if it applies to him. Time and lives intersect through these moments that are clubbed together. The fan becomes another character which unites Auntie Deshpande, Ila and Saajan: in one shot, Ila stares at the fan while her husband comes late and in the "same" scene Saajan also stares at the fan in his office. Like the dabba, the fan becomes a life-providing character that joins the desire of these three separate characters.

At yet another moment, Saajan is seen on the train one evening. His voice speaks the words he wrote to Ila earlier on at lunch time. He is shown on the screen several hours later, performing the gestures he was telling her about, while she is seen reading his letter. The chronological axis is totally disrupted.

The diegetic voice-over (Saajan's or Ila's) that is regularly used in the film, the flash-backs and the editing, all denote the reconstruction of time and space through the reconstruction of scenario and screen image. The impact is aesthetic, philosophical and political, pointing to the necessity for art to introduce irregularity, disruption and breaks in the narrative: it is the only way to have a space of freedom emerge in certain contexts that are otherwise locked for certain categories of the population. Once this irregularity has been introduced, movement is there, in all meanings of the term-visually, temporally, psychologically, but above all socially and politically.

The movement which is reinitiated creates a different relationship to the self and induces a reinvention of self. The adventure in which Ila and Saajan are implicated takes them back to moments in their own past, childhood or adulthood, to their relationships to their mothers, parents, siblings or spouses. Old films and songs are re-discovered and listened to again, creating for themselves another imaginary space the characters can share with the other. Significantly enough, one popular song establishes a more acute connection, "Pardesi, Pardesi" $: 8$ it is sung by the shoe shine boy/man when Saajan is on the train; it is also a song that Auntie Deshpande plays on her cassette-player. Ila listens to it one floor down but asks Auntie to turn it off when her husband comes back home, because she is afraid he would not like it, thus signalling that her own home does not truly belong to her, she is not at home in her own home. Other examples of such connections are the television cooking shows that Saajan's wife and Ila's mother used to watch at about the

8. "Foreigner, foreigner, keep me in your thoughts, don't forget me." 
same period, but separately. Gradually Ila goes back to her own personal memories, all the more acutely as her father has just died. He had been looked after by Ila's mother and his death prompts a narrative from Ila's mother that Ila had not expected. All these characters' memories, narratives and desires cross and intersect, yielding a new creative, intimate and imaginary space. Like the English that is used in the letters, music and memories offer a possibility of escape. It is one escape route that is just as valid as the one Ila contemplates at the end of the film-going to Bhutan, leaving the Hindu-dominated nation that does not encourage women to be what they want to be.

Throughout the film, the dialogue outside the window with Auntie's disembodied voice goes on. It is Auntie who encourages Ila to put more chili in the food when Saajan complained about the salt, or to respond to the letters; she advises her on many things and offers comfort. Yet, Ila does not share everything with her. And once she has taken the initiative of suggesting a meeting, Auntie's voice does not feature in the film anymore, it simply stops and the spectator could even wonder how real that voice was. Only Ila's voice and desire are eventually to be heard. Once she becomes her own agent, she does not need anyone else, not Auntie, and not even Saajan. Renewed desire for the other leads to agency and self-empowerment. To arrive at such a reformulation, the film needed the detour through the reconstruction of time and space. It also needed a certain type of editing, potent and perky, yet delicate and subtle. Borrowing Laura Mulvey's words, it could be said that "[p]laying on the tension between film as controlling the dimension of time (editing, narrative) and film as controlling the dimension of space (changes in distance, editing), cinematic codes create a gaze, a world, and an object, thereby producing an illusion cut to the measure of desire" (Mulvey 17).

Paradoxically, the only character who is not granted psychological development is the dabbawallab himself. It could be said that, in the wake of the Subaltern Studies Group that emerged in the 1980s, the film focuses on people from below, on subalterns (Guha). Yet, far from showcasing these people of allegedly lesser importance as potential agents of change and renewal, as Ranajit Guha had implied, it seems on the contrary that the film eschews the social perspective on the subaltern that would have been the raison d'être of a documentary. Instead, it favours a perspective on Ila and Saajan, a more emotional and individual one, as if it had become the only one possible. The one occasion to foreground the dabbawallah happens on one of the days when he delivers the dabba back to Ila's house in the afternoon and she lets him know about the mistake that has been recurring. The dabbawallah never steps out of his social role as dabbawallah, he even defends the whole system and asserts that such mistakes cannot occur. From the narrative point of view however, it is the mistake that makes the romance possible by opening up a space that wasn't there before. The crack in the well-oiled system is what makes the plot turn and move forward. 
However, the fact that the dabbawallab is never granted any personal, psychological status, contrary to all the other characters, is also a point that is made by the film: in Indian society, one is bound to the constricted social roles that one has been attributed originally. It is extremely difficult to challenge them and move away. Had the film remained a documentary as it had been intended, the dabbawallab would certainly have been the main focus of the film. It is very interesting that he should have been deprived of such a first role, as if it was a structural impossibility for a dabbawallah to be granted first role status in a movie, be it fiction or non-fiction. The choice that is made is comedy, romance, and a love story that, even if thwarted, manages to create new spaces of interaction and invention.

The film does not zoom in on the most under-privileged sections of Indian society in a direct fashion but by focusing on one (small) section only, it implicitly and obliquely zooms out of other portions of society. Ila and Saajan are not under-privileged but they are sectioned off and marginalized in all kinds of subtle and perverse ways that make the audience guess that it must be much worse for other, more under-privileged sections of society. Through the angle of romance and the genre of dramatic comedy, Ritesh Batra offers us a parallax view of Indian society. If we follow Zizek's definition, the parallax view is "the apparent displacement of an object (the shift of its position against a background), caused by a change in observational position that provides a new line of sight" (Zizek). The fact that the film is the result of an Indo-French-GermanAmerican collaboration may add another dual element: it draws the film farther away from the "Shining India" of Bollywood and Kollywood and closer to the genre of repertory or independent cinema. Far from providing any distortion but simply shifting his point of view, and ours, on the object, Batra radically unsettles the perspective, and creates resistance by encouraging his audience to circumvent or "elude the politics of polarity and emerge as the others of our selves" (Bhabha 39). This is an aesthetic gesture of course, and as such, a highly political one since it goes against the flow of the current political evolution in India.

Joshil K. ABRAHAM

G. B. Pant Engineering College

Indraprastha University, Delhi

Judith MISRAHI-BARAK

Université Paul Valéry Montpellier 3 EMMA EA 741 


\section{Bibliography}

Batra, Ritesh. The Lunchbox. UTV, 2014.

Bhabha, Homi. The Location of Culture. London: Routledge, 1994.

Deleuze, Gilles. Cinéma 2 - L'Image-Temps. Paris : Minuit, 1985.

Derrida, Jacques. "Semiology and Grammatology: Interview with Julia Kristeva." The Communication Theory Reader. Ed. Paul Cobley. London: Routledge, 1996. 206-24.

Guha, Ranajit, ed. Subaltern Studies Reader, 1986-95. Minneapolis: University of Minnesota Press, 1997.

Lacan, Jacques. "La Lettre volée ». La psychanalyse 2 (1957): 15-44.

Mulvey, Laura. "Visual Pleasure and Narrative Cinema". Screen 16.3 (Autumn 1975): 6-18.

$<$ http://imlportfolio.usc.edu/ctcs505/mulveyVisualPleasureNarrativeCinema. pdf >, last accessed 15/02/2015.

Thomke, Stefan. "Mumbai's Models of Service Excellence." Harvard Business Review (November 2012): 1-7.

Zizek, Slavoj. "The Parallax View". < http://www.lacan.com/zizparallax.htm >, last accessed 15/02/2015. 


\section{ÉTUDES ANGLAISES}

\section{Articles}

EUGENIO F. BIAGINI

Home Rule for Ireland (1874-1914):

the Great Missed Opportunity?

FIONA MCCANN

Borders, Barriers and Kinopolitics in Nadine Gordimer's Jump and Other Stories (1991)

CHRISTINE SUKIC

"Such a mistake as I have often seen / In a play":

The Duchess of Malfi, a Tragedy of Errors

MICHEL IMBERT

The Confidence-Man : I'inconfiance de l'homme des foules

Atonement: A Conversation with Ian McEwan.

Edited by Vanessa Guignery

\section{Varia}

JOSHIL K. ABRAHAM AND JUDITH MISRAHI-BARAK

The Lunchbox and Mumbai's Dabbawallahs:

Creating Spaces of Desire

\section{Comptes rendus}
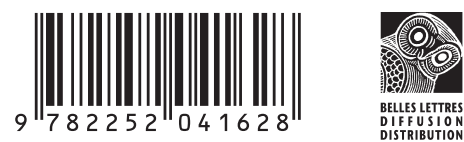

ISBN : 978-2-252-04162-8

ISSN 0014-195X 